\title{
PENTINGNYA PENGENDALIAN SUPPLY BAHAN BAKU DALAM AKTIVITAS PROSES PRODUKSI PADA RUMAH SUSTAINABLE ASSEMBLY PADA INDUSTRI RUMAH DI JABON SIDOARJO
}

\author{
Ennis Mufaridah $^{1)}$, Fiskha Suhartini ${ }^{2)}$ \\ ${ }^{1,2)}$ Program Studi Manajemen, Universitas Narotama Surabaya \\ ${ }^{1)}$ E-Mail: ennismufaridah22@gmail.com \\ ${ }^{2)}$ E-Mail: fiskhasuhartini@gmail.com
}

\begin{abstract}
Home industry that has been the backbone of local government, always in galakkan to improve the dignity of society of lower economic class which generally become small business actor, in business activity important factor to be considered is controlling raw material, so easy to be controlled and not damaged then the amount of raw materials to be purchased in accordance with the needs, so that it can be minimized the amount of raw materials that tend to be damaged. Thus, raw materials purchased can be efficient for production process activities.
\end{abstract}

\section{Keywords: inventory, production process, home industry.}

Abstrak. Industri rumahan yang telah menjadi tulang punggung pemerintah daerah, selalu dalam galakkan untuk meningkatkan martabat masyarakat kelas ekonomi bawah yang umumnya menjadi pelaku usaha kecil, dalam kegiatan bisnis faktor penting yang harus diperhatikan adalah pengendalian bahan baku, sehingga mudah dikendalikan dan tidak rusak maka jumlah bahan baku yang akan dibeli sesuai dengan kebutuhan, sehingga dapat diminimalkan jumlah bahan baku yang cenderung rusak. Dengan demikian, pembelian bahan baku bisa efisien untuk kegiatan proses produksi.

\section{Kata kunci : persediaan, proses produksi, industri rumah tangga}

\section{PENDAHULUAN}

Perekonomian saat ini telah berkembang pesat, seiring dengan perkembangan pesat Sains dan Teknologi (IPTEK). Jadi persaingan antar perusahaan menjadi semakin ketat. Setiap perusahaan pasti memiliki tujuan yang sama yaitu mendapatkan untung. Untuk mencapai tujuan tersebut dipengaruhi oleh beberapa faktor, Salah satu faktor yang mempengaruhi masalah kelancaran produksi. Setiap perusahaan selalu membutuhkan inventaris. Tanpa pasokan pengusaha akan terkena risiko bahwa perusahaannya pada satu waktu tidak dapat memenuhi keinginan pelanggannya. Jadi persediaan sangat penting bagi perusahaan baik yang menghasilkan barang maupun jasa.

\section{KAJIAN TEORI}

\section{Memahami Persediaan dan Pengendalian Persediaan Bahan Baku}

Menurut Ristono (2011) persediaan adalah barang yang disimpan untuk digunakan atau dijual di masa depan atau periode yang akan datang. Dalam bukunya menyatakan bahwa pengendalian persediaan adalah salah satu kegiatan rangkaian kegiatan berturut-turut satu sama lain dalam semua operasi produksi perusahaan sesuai dengan apa yang telah direncanakan sebelumnya baik waktu, kuantitas, kuantitas dan biaya. Jika perusahaan menyimpan terlalu banyak uang dalam persediaan, menyebabkan biaya penyimpanan yang berlebihan, dan mungkin memiliki "Biaya Peluang" (dana dapat diinvestasikan dalam investasi yang lebih 
menguntungkan.) Sebaliknya, jika suatu perusahaan tidak memiliki persediaan yang cukup dapat menyebabkan biaya yang harus dibayar Untuk kekurangan bahan Sehingga, dapat disimpulkan bahwa pengendalian persediaan sangat penting untuk kelancaran proses produksi yang akhirnya mampu menghasilkan pendapatan pendapatan.

\section{Jenis Inventaris}

Menurut Ristono (2011), berdasarkan tujuan persediaan dibagi menjadi tiga jenis, yaitu sebagai berikut:

1. Keamanan stok:

2. Antisipasi inventarisasi:

3. Persediaan pengiriman (transit stock):

\section{Fungsi Inventaris}

Menurut Muslich (2012) dalam bukunya menyatakan bahwa persediaan memiliki fungsi yang sangat penting bagi perusahaan. Berdasarkan berbagai macam barang yang ada seperti bahan, barang dalam proses dan barang jadi, perusahaan menyimpannya karena berbagai alasan. Alasannya adalah sebagai berikut:

1. Temui pesanan

2. Berjaga-jaga

3. Menekan biaya dan biaya produksi

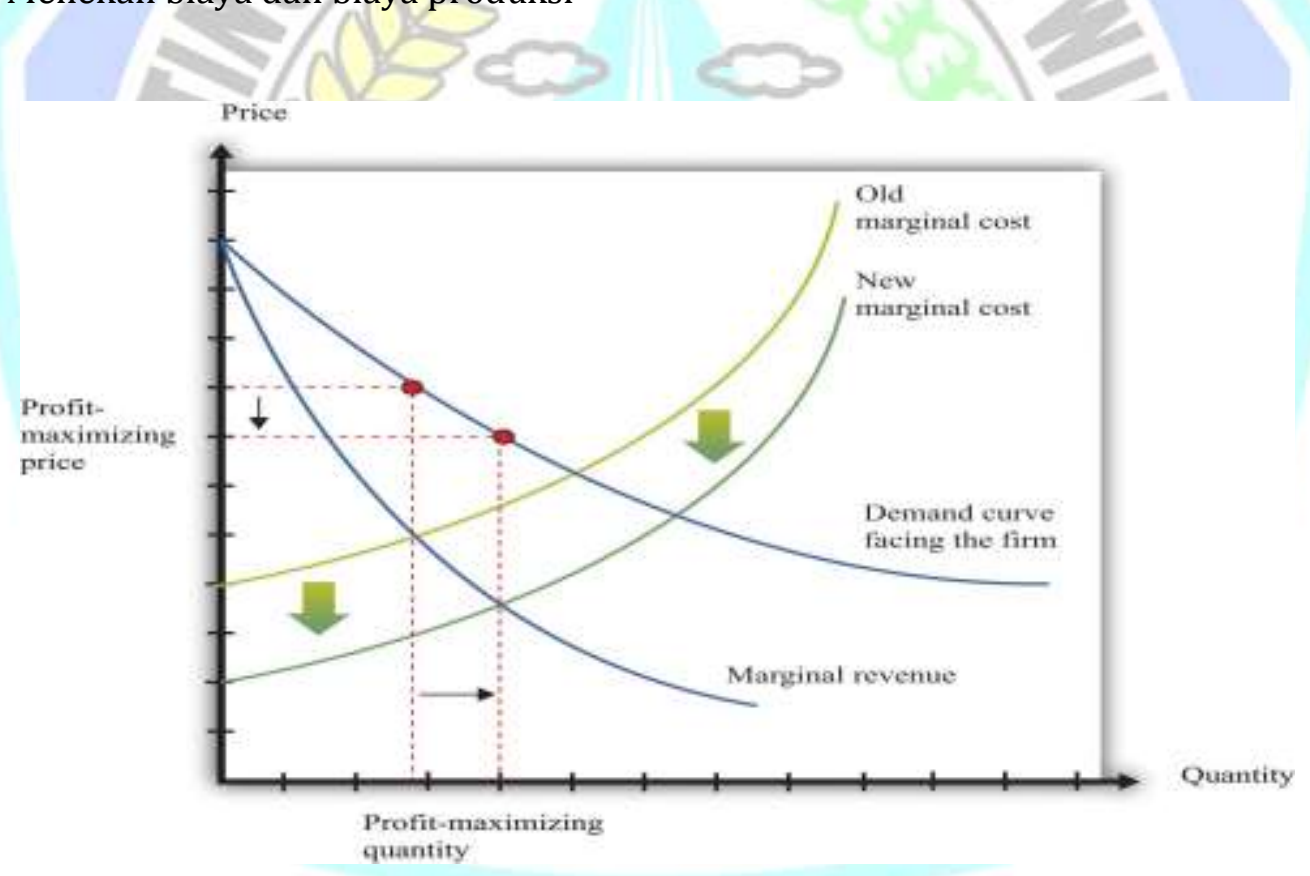

\section{Gambar 1. Kurva penawaran bahan baku di sebuah perusahaan}

Sumber: \{ HYPERLINK "https://saylordotorg.github.io/text_microeconomicstheory-through-applications/s12-01-how-do-firms-decide-how-many-h.html" \}

\section{Cara Mengendalikan Persediaan Bahan Baku}

Setiap perusahaan memiliki cara berbeda dalam mengimplementasikan persediaan bahan bakunya. Cara atau teknik persediaan bahan baku adalah ukuran yang sangat penting untuk menghitung jumlah persediaan bahan baku yang harus tersedia dan kapan harus mulai memesan ulang.

Ada beberapa metode pasokan bahan baku yang bisa digunakan menurut Heyzer (2010), antara lain: 
1. Metode analisis ABC

2. Metode pengendalian persediaan

3. Persediaan dalam kondisi tidak pasti dan ada pesanan kembali.

4. Inventarisasi dalam kondisi tidak menentu dan tidak ada pemesanan ulang.

5. Inventarisasi sistem tepat pada waktunya

Menurut Hyzer (2010) ada beberapa model persediaan bahan baku yang sering digunakan dalam sistem.

\section{Model Inventarisasi Bahan Baku}

1. Inventaris sistem pembatas. Manajemen menggunakan metode ini akan menentukan batas minimum dan batas maksimum persediaan bahan baku yang digunakan di perusahaan. Inventarisasi bahan baku yang ada dapat dilakukan secara berkala dalam jangka waktu tertentu, misalnya, setiap hari, setiap minggu, setiap bulan dan seterusnya

2. Kotak sistem inventaris. Inventaris ini tidak mengenali periode pemeriksaan ulang, oleh karena itu persediaan bahan baku ini akan segera terlihat di kotak yang digunakan sebagai penyimpanan bahan baku. Dengan cara ini pembelian bahan baku akan dilakukan ketika jumlah bahan baku dalam kotak yang digunakan sebagai tempat persediaan bahan baku telah mencapai batas waktu tertentu.

3. Inventarisasi visual. Inventaris visual adalah persediaan bahan mentah dengan menggunakan kartu pengeluaran bahan yang berbeda. Dengan cara ini manajemen dapat mengetahui tingkat persediaan yang ada hanya dengan melihat warna pengeluaran warna yang dikeluarkan bahan kartu.

\section{Memahami Kelancaran Proses Produksi}

Kelancaran adalah apa yang diinginkan semua orang dalam aktivitas apa pun. Karena kelancaran tujuan yang diinginkan atau direncanakan dapat dicapai tanpa gangguan signifikan dalam kegiatan proses. Menurut Artaya (2018) dalam bukunya, dasar-dasar operasi dan manajemen produksi menyatakan fungsi produksi adalah kegiatan untuk menciptakan atau meningkatkan kegunaan suatu barang, mengubah sesuatu yang bernilai lebih rendah menjadi sesuatu yang memiliki nilai lebih tinggi dengan menggunakan sumber daya yang ada., seperti bahan baku bahan, tenaga kerja, mesin dan sumber lainnya, sehingga produk yang dihasilkan dapat memberikan kepuasan kepada konsumen.

Empat fungsi terpenting dalam fungsi produksi dan operasi adalah:

1. Proses pengolahan, merupakan metode atau teknik yang digunakan untuk memproses input (input)

2. Layanan pendukung, adalah sarana dalam bentuk pengorganisasian yang diperlukan untuk penentuan teknik dan metode yang akan dijalankan, sehingga proses pengolahan dapat dilaksanakan secara efektif dan efisien.

3. Perencanaan, adalah penentuan keterkaitan dan pengorganisasian kegiatan produksi dan operasi yang akan dilakukan dalam waktu atau periode waktu tertentu

4. Kontrol atau pemeliharaan, adalah fungsi untuk memastikan pelaksanaan kegiatan sesuai dengan yang direncanakan, sehingga tujuan dan tujuan penggunaan dan pengolahan input (input) sebenarnya dapat dilaksanakan. 


\section{METODE PENELITIAN}

\section{Lokasi Penelitian}

Terletak di desa Sidoarjo, Jawa Timur, Jabon pada kelompok industri produk ekspor yang berkualitas ekspor. Lokasi ini memiliki potensi untuk sangat mengembangkan kegiatan industrinya, untuk pasar lokal dan pasar global.

\section{Metode Sampling}

Subyek penelitian ini melibatkan 24 pengusaha, yang semuanya memiliki fokus yang sama yaitu pemenuhan pangsa pasar ekspor. Mereka telah lama memproduksi dalam industri ini dan telah menjelajahi beberapa pasar potensial di luar negeri.

\section{Metode Analisis Data}

Untuk keperluan pengambilan keputusan dalam penelitian ini, pendekatan yang paling relevan adalah menggunakan analisis regresi linier berganda atas dasar persamaan estimasi. Jadi fokus keputusan dapat dibuat dengan hak minimal untuk mendekati kondisi yang sebenarnya (Santoso, 2015). Persamaan dari model regresi:

$\mathrm{Y}=\mathrm{bo}+\mathrm{b} 1 . \mathrm{X} 1+\mathrm{b} 2 . \mathrm{X} 2+\mathrm{b} 3 . \mathrm{X} 3+\mathrm{b} 4 . \mathrm{X} 4$

Variabelnya:

$\mathrm{Y}=$ Ekspansi Pasar

$\mathrm{X} 1$ = Pasokan Bahan

$\mathrm{X} 2$ = Biaya Produksi

$\mathrm{X} 3$ = Jaringan Bisnis

$\mathrm{X} 4=$ Peraturan Pemerintah

b0, b1, b2, b3, b4 koefisien regresi sebagai parameter adalah keputusan dalam estimasi aktivitas, yang menandai koefisien kecil kecilnya.

(e) = nilai variabel pengganggu yang tidak dibahas dalam model.

\section{HASIL DAN PEMBAHASAN}

Hasil analisis regresi untuk pengambilan keputusan dalam penelitian ini, dapat disajikan sebagai berikut:

\section{Tabel 1. Hasil Analisis Regresi Linier Berganda}

\section{Model Summaryb}

\begin{tabular}{|c|c|c|c|c|}
\hline Model & $\mathrm{R}$ & R Square & $\begin{array}{ll}\text { Adjusted } & R \\
\text { Square } & \end{array}$ & $\begin{array}{l}\text { Std. Error of } \\
\text { the Estimate }\end{array}$ \\
\hline 1 & ,937a & 878, & ,853 & ,270 \\
\hline & & & & \\
\hline & & & & \\
\hline & & & & \\
\hline & & & & \\
\hline & & & & \\
\hline
\end{tabular}

a. Predictors: (Constant), Government Regulations, Business

Network, Cost of Production, Supply of Materials

b. Dependent Variable: Market Expansion 


\begin{tabular}{|c|c|c|c|c|c|c|}
\hline \multicolumn{7}{|c|}{ ANOVA $^{b}$} \\
\hline & & $\begin{array}{l}\text { Sum of } \\
\text { Squares }\end{array}$ & $\mathrm{df}$ & Mean Square & $\mathrm{F}$ & Sig. \\
\hline 1 & $\begin{array}{l}\text { Regression } \\
\text { Residual } \\
\text { Total }\end{array}$ & $\begin{array}{l}9,953 \\
1,380 \\
11,333\end{array}$ & $\begin{array}{l}4 \\
19 \\
23\end{array}$ & $\begin{array}{l}2,488 \\
, 073\end{array}$ & 34,260 &, $000^{a}$ \\
\hline
\end{tabular}

a. Predictors: (Constant), Government Regulations, Business Network, Cost of Production, Supply of Materials

b. Dependent Variable: Market Expansion

\section{Coefficients $^{a}$}

\begin{tabular}{|ll|l|l|l|l|l|}
\hline \multicolumn{2}{|l|}{ Model } & \multicolumn{2}{|l|}{$\begin{array}{l}\text { Unstandardized } \\
\text { Coefficients }\end{array}$} & $\begin{array}{l}\text { Standardiz } \\
\text { ed } \\
\text { Coefficients }\end{array}$ & & \\
\cline { 2 - 5 } & $\mathrm{B}$ & Std. Error & Beta & $\mathrm{t}$ & Sig. \\
\hline 1 & (Constant) &,- 950 &, 592 & & $-1,605$ &, 125 \\
& Supply of Materials &, 894 &, 121 &, 832 & 7,371 &, 000 \\
& Cost of Production &, 176 &, 100 &, 154 & 1,755 &, 095 \\
& Business Network &, 109 &, 075 &, 133 & 1,451 &, 163 \\
& Government &, 049 &, 084 &, 056 &, 582 &, 567 \\
& & & & & \\
\hline
\end{tabular}

a. Dependent Variable: Market Expansion

\section{Residuals Statistics}

\begin{tabular}{|c|c|c|c|c|c|}
\hline & Minimum & Maximum & Mean & $\begin{array}{l}\text { Std. } \\
\text { Deviation }\end{array}$ & $\mathrm{N}$ \\
\hline Predicted Value & 2,78 & 5,09 & 3,83 & ,658 & 24 \\
\hline Std. Predicted Value & $-1,598$ & 1,910 &, 000 & 1,000 & 24 \\
\hline $\begin{array}{l}\text { Standard Error of } \\
\text { Predicted Value }\end{array}$ &, 060 &, 189 &, 119 & ,033 & 24 \\
\hline $\begin{array}{l}\text { Adjusted Predicted } \\
\text { Value }\end{array}$ & 2,71 & 5,12 & 3,84 &, 660 & 24 \\
\hline Residual &,- 911 & ,218 &, 000 &, 245 & 24 \\
\hline Std. Residual & $-3,382$ & ,809 &, 000 & ,909 & 24 \\
\hline Stud. Residual & $-3,470$ &, 938 &,- 008 & 1,017 & 24 \\
\hline Deleted Residual &,- 959 & ,302 &,- 006 & ,317 & 24 \\
\hline Stud. Deleted Residual & $-5,580$ &, 935 &,- 116 & 1,394 & 24 \\
\hline Mahal. Distance &, 195 & 10,379 & 3,833 & 2,434 & 24 \\
\hline Cook's Distance &, 001 & 1,159 & ,068 & ,235 & 24 \\
\hline $\begin{array}{l}\text { Centered Leverage } \\
\text { Value }\end{array}$ & ,008 &, 451 &, 167 &, 106 & 24 \\
\hline
\end{tabular}

a. Dependent Variable: Market Expansion 

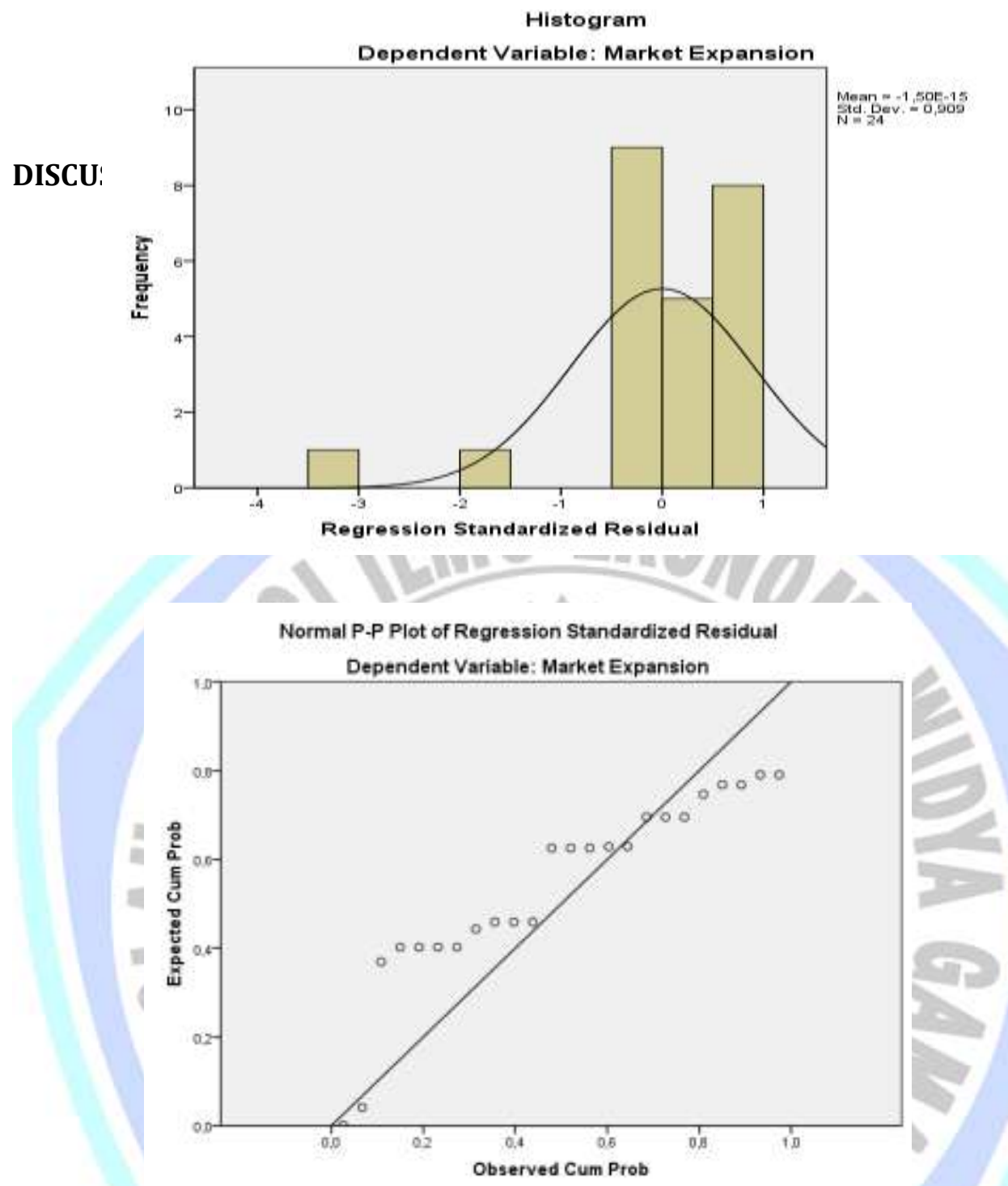

\section{HASIL DAN PEMBAHASAN}

Ada beberapa hasil yang perlu kita rujuk ke analisis regresi linier berganda melalui di atas, yaitu:

1. Pasokan bahan, menunjukkan hasil yang signifikan berarti bahwa semua bentuk aktivitas perusahaan dari ketersediaan bahan sudah berjalan dengan baik dan tidak ada masalah yang berarti. Berarti bahan baku telah dijamin untuk kegiatan kelompok bisnis ini.

Biaya produksi ternyata menjadi hasil yang tidak signifikan, artinya dalam kegiatan proses produksi, masih ditemukan adanya kegiatan yang tidak efisien dalam upaya memangkas biaya produksi, maka akan menjadi tugas perusahaan untuk melakukan dengan baik sebelum perluasan pasar.

2. Jaringan bisnis hasilnya ternyata tidak signifikan, artinya secara internal, perusahaan masih mengalami kendala dalam kegiatan ekspansi pasar dari perspektif bisnis jaringan. Ini adalah tugas dari kelompok-kelompok industri agar memiliki peluang untuk masuk ke pasar global.

3. Pemerintah harus mendukung kegiatan kelompok industri, karena tugas Pemerintah adalah untuk memfasilitasi pencapaian tujuan dalam perluasan pasar 
melalui serangkaian peraturan yang pada dasarnya meluncurkan usaha kelompok usaha dalam mencapai tujuan perluasan pasar.

\section{PENUTUP}

\section{Simpulan}

Berdasarkan uraian di atas, penulis menyimpulkan bahwa pelaksanaan persediaan bahan baku dalam hal ini pengendalian bahan baku sangat penting untuk kelancaran proses produksi. Karena bahan bakunya merupakan unsur yang sangat penting dalam produksi, keberadaan persediaan bahan baku termasuk pengendalian harus dipertimbangkan. Seharusnya tidak berlebihan dan berkurang. Sebab, dengan kelebihan persediaan bahan baku menimbulkan biaya besar yang dalam hal ini akan mengurangi laba perusahaan. Demikian juga, pasokan bahan baku yang kurang dari akan menghambat proses produksi juga cenderung menyebabkan biaya pembelian bahan akan membesar. Karena pembelian yang tidak dilakukan biasanya lebih mahal dari harga normal. Dengan demikian, itu juga akan menimbulkan biaya lebih besar dan mengurangi keuntungan perusahaan.

\section{Saran}

Setiap perusahaan harus dapat mempertimbangkan beberapa hal di bawah ini sehingga proses produksi dapat berjalan dengan lancar dan pencapaian tujuan perusahaan, terutama laba dapat tercapai. Itu adalah:

1. Berapa jumlah unit persediaan bahan baku yang akan diadakan di dalam perusahaan.

2. Kapan dan berapa banyak unit bahan baku akan dibeli oleh perusahaan.

3. Ketika perusahaan bersangkutan akan melakukan pembelian kembali, jika persediaan bahan baku di perusahaan dianggap telah habis.

Jika hal di atas sudah dipertimbangkan maka kemungkinan risiko yang muncul akan berkurang bahkan bisa hilang, termasuk proses produksi dapat berjalan dengan lancar dan keuntungan maksimal.

\section{DAFTAR RUJUKAN}

Artaya, I Putu. 2012, Wiraniaga - Membangun Jaringan Penjualan, Narotama University Press, Surabaya.

Artaya, I Putu., 2018, Dasar-Dasar Manajemen Operasi dan Produksi, Narotama University Press, Surabaya.

Artaya, I Putu., Arimbawa, IG. 2018, Penerapan Metode Korelasi dalam Mengukur Hubungan Antara Customer Relationship dengan Customer Loyalty Pada PT. Antika Raya Surabaya, Jurnal Bisnis dan Manajemen Universitas Negeri Surabaya. Vol. 1, No. 1.

Artaya, I Putu.,Kamisutara, Made., Baktiono, R Agus., 2018, Pengaruh Citra Produk Berdasarkan Analisis Persepsi Konsumen Pada Kelompok Usaha Aneka Pangan Di Sidoarjo, E-Jurnal Tata Sejuta STIA Mataram, Vol. 4, No. 1.

Handoko. (2000). Pengendalian Produksi. Jakarta: Alpabetha

Heizer, Jay. (2010). Operations Manajemen. Salemba Empat : Jakarta

Muslich. 2012. Metode Pengambilan Keputusan Kuantitatif. Bumi Aksara: Jakarta. 
Rangkuti, Freddy. (1996). Manajemen Persediaan. Rajawali Pers: Jakarta

Render, Barry dan Jay Heyzer. (2005). Operation Management. Terjemahan oleh Ir. Kresnohadi Ariyoto, MBA Salemba Empat. Jakarta.

Ristono, Agus. 2011. Manajemen Persediaan. Yogyakarta: Graha Ilmu.

Santoso, Singgih., 2015., Mengukur Sikap dan Kepuasan Konsumen Aplikasi SPSS, Penerbit Elex Media Komputindo, Jakarta.

Soekiman JFXS., Baktiono, R. Agus, Artaya, I Putu., 2018, Optimization of governance model of post-food harest and distribution in msme centers in 5 subdistricts in sidoarjo regency, Journal of Economics, Business \& Accountancy Ventura, Vol. 20, No. 3. 